УДК 629.4.027

\title{
ДО ПИТАННЯ ОЦІНКИ НАДІЙНОСТІ БУКСОВИХ ВУЗЛІВ КРИТИХ УНІВЕРСАЛЬНИХ ВАГОНІВ
}

Д-р техн. наук І.Е. Мартинов, канд. техн. наук А.В. Труфанова, інж. В.М. Ільчишин

\section{К ВОПРОСУ ОЦЕНКИ НАДЕЖНОСТИ БУКСОВЫХ УЗЛОВ КРЫТЫХ УНИВЕРСАЛЬНЫХ ВАГОНОВ}

Д-р техн. наук И.Э. Мартынов, канд. техн. наук А.В. Труфанова, инж. В.М. Ильчишин

\section{THE ISSUE OF ASSESSMENT OF THE RELIABILITY OF AXLEBOX UNITS COVERED} UNIVERSAL CARS

Doct. of techn. sciences I. Martynov, cand. of techn. sciences A. Trufanova, engineer V. Ilchyshin

У статті аналізується технічний стан елементів буксових вузлів вантажних вагонів. Показано, щяо довговічність буксових підшипників не відповідає вимогам нормативних документів. Установлені найбільи небезпечні для забезпечення безпеки руху пошкодження роликових букс. Отримано залежності, які характеризують зміну параметра потоку відмов для роликових букс $з$ циліндричними роликовими підшипниками. Доведено, що параметр потоку відмов буксових вузлів у критих універсальних вагонів менше порівняно із середніми показниками по вагонному господарству.

Ключові слова: буксовий вузол, циліндричний роликовий підшипник, критий універсальний вагон, відмова, надійність, безпека руху.

В статье анализируется техническое состояние элементов буксовых узлов грузовых вагонов. Показано, что долговечность буксовых подшипников не отвечает требованиям нормативных документов. Установлены наиболее опасные для обеспечения безопасности движения повреждения роликовых букс. Получены зависимости, характеризующие изменение параметра потока отказов для роликовых букс с изилндрическими роликовыми подшипниками. Доказано, что параметр потока отказов буксовых узлов у крытых универсальных вагонов меньше по сравнению со средними показателями по вагонному хозяйству.

Ключевые слова: буксовый узел, иилиндрический роликовый подиипник, крытый универсальный вагон, отказ, надежность, безопасность движения. 
The article analyzes the technical condition of elements of axlebox units of freight cars. It is shown that durability of axlebox bearings do not meet the requirements of normative documents. Installed the most hazardous to traffic safety, the damage to the roller axle box. $25 \%$ are caused by failure of the mechanical fastening. Further there are failures caused by the influence of "the human factor" - non-observance of technology of installation works. This includes damage such as electrical burns on the surfaces of the rings and rollers, improper radial and axial clearance in the bearing, insufficient or excess grease, embedded in the bearings.

A significant part by the damage to the memory riser card (almost $13.5 \%$ ).

The hope that the use of cylindrical roller bearings will solve the problem of providing for reliability $B V$ cars, failed to materialize fully.

One of the ways to improve the reliability of roller axle-boxes can be bearings, cassette type, which should be a resource not less than 800 thousand kilometers.

Dependences describing change of failures stream parameter for roller axle box with cylindrical roller bearings. it is proved that the parameter failures flow axle assemblies of indoor universal cars less compared with the average for the вагонному есопоту.

Keywords: axle boxes, cylindrical roller bearing, covered universal cars, refusal, reliability, safety.

Вступ. Залізничний транспорт являе собою особливу транспортну систему, що працює в складних умовах та виконує переважну більшість вантажних і пасажирських перевезень. Умовою успішного та конкурентоспроможного функціонування залізниць $є$ забезпечення перевезення вантажів iз максимально допустимою швидкістю та мінімальною собівартістю за умов забезпечення безпеки руху.

Безупинна експлуатація вантажних вагонів при високих швидкостях руху та збільшених пробігах багато в чому залежить від надійної роботи буксових підшипникових вузлів вантажних вагонів. Недостатне фінансування галузі призвело до значного зменшення постачання нового рухомого складу та суттєвого старіння вагонного парку.

За останні роки на залізницях України ситуація із забезпеченням безпеки у вагонному господарстві істотно загострилася, оскільки збільшилася кількість відчеплень вагонів через відмови роликових букс. Крім того, перспективи інтеграції України у систему світових економічних відносин вимагають, щоб характеристики перспективних буксових підшипникових вузлів відповідали не лише національним, але і світовим стандартам.

Аналіз останніх досліджень i публікацій. На залізницях України та інших країн СНД 3 60-х років $\mathrm{XX}$ сторіччя використовуються буксові вузли (БВ), обладнані двома циліндричними підшипниками [0]. У порівнянні зі сферичними підшипниками вони мали низку переваг [0], оскільки багатьма дослідженнями $[0,0]$ підтверджено, що використання роликових підшипників дало змогу в 70 разів зменшити число відчеплень вагонів на шляху прямування через надмірний нагрів букс.

Проте у кінці минулого сторіччя кількість відмов роликових букс різко збільшилась. Так, за даними дослідження [0], за період 19771987 pp. на залізницях СРСР кількість відчеплень вагонів через нагрів БВ збільшилась більш ніж у 6 разів, суттєво перевищуючи темпи насичення вагонного парку вагонами, обладнаними підшипниками кочення. $90 \%$ $\gamma$-ресурс циліндричних буксових підшипників складав всього 6 років експлуатації. Фактична витрата підшипників при проведенні планових видів ремонту в 5 разів перевищувала значення, встановлені нормативними документами.

Дослідження, проведені фахівцями Української державної академії залізничного транспорту $[0,0,0]$, підтвердили, що буксові вузли вантажних вагонів мають недостатню надійність.

Таким чином, сподівання на те, що використання циліндричних роликових підшипників дасть змогу вирішити проблеми із забезпеченням надійності БВ вагонів, не виправдалися повною мірою.

Одним зі шляхів підвищення надійності роликових букс може бути використання підшипників касетного типу [0], які повинні мати ресурс не менше 800 тис. км пробігу.

У той же час необхідно зазначити, що останнім відбулася реструктуризація вагонного парку, внаслідок якої переважна більшість 
вагонів була розподілена між певними операторами, які стали не лише власниками вантажних вагонів, а й отримали відповідальність за підтримання вагонів у належному технічному стані. Так, власником критих універсальних вагонів стало державне підприємство "Укррефтранс".

Але інтенсивність використання вантажних вагонів різних типів дуже відрізняється. А нормативні документи стосовно забезпечення необхідного ресурсу буксових підшипників це не враховують.

Визначення мети та задачі дослідження. Мета роботи полягає у порівняльному аналізі показників надійності роликових букс, що використовуються в колісних парах універсальних критих вагонів та обгрунтуванні можливості встановлення диференційованого терміну експлуатації підшипників касетного типу.

Основна частина дослідження. За даними УЗ, кількість відчеплень вагонів через надмірний нагрів роликових букс, який був виявлений приладами контролю, коливається у широких межах: від 352 випадків у 1995 році до 51 випадку у 2011 році. Але до цієї кількості необхідно додавати випадки виявлення підвищеногоого нагрівуу роликових підшипникових вузлів за зовнішніми ознаками оглядачами вагонів. У 2011 році це число складало 1122 вагони (рис. 1)

Аналіз причин нагріву БУ буксових вузлів свідчить, що найбільш небезпечним 3 точки зору забезпечення безпеки руху $\epsilon$ пошкодження торцевого кріплення (майже 25 \% від загальної кількості відчеплень). Далі йдуть відмови, викликані впливом "людського чинника" - недотриманням технології монтажних робіт. Сюди включено такі пошкодження, як електричні опіки на поверхнях кілець i роликів, неправильно підібрані радіальний та осьовий зазори в підшипнику, недостатня або надмірна кількість мастила, закладеного в підшипники.

Значну частину займають пошкодження типу "ялинка" (майже 13,5 \%).

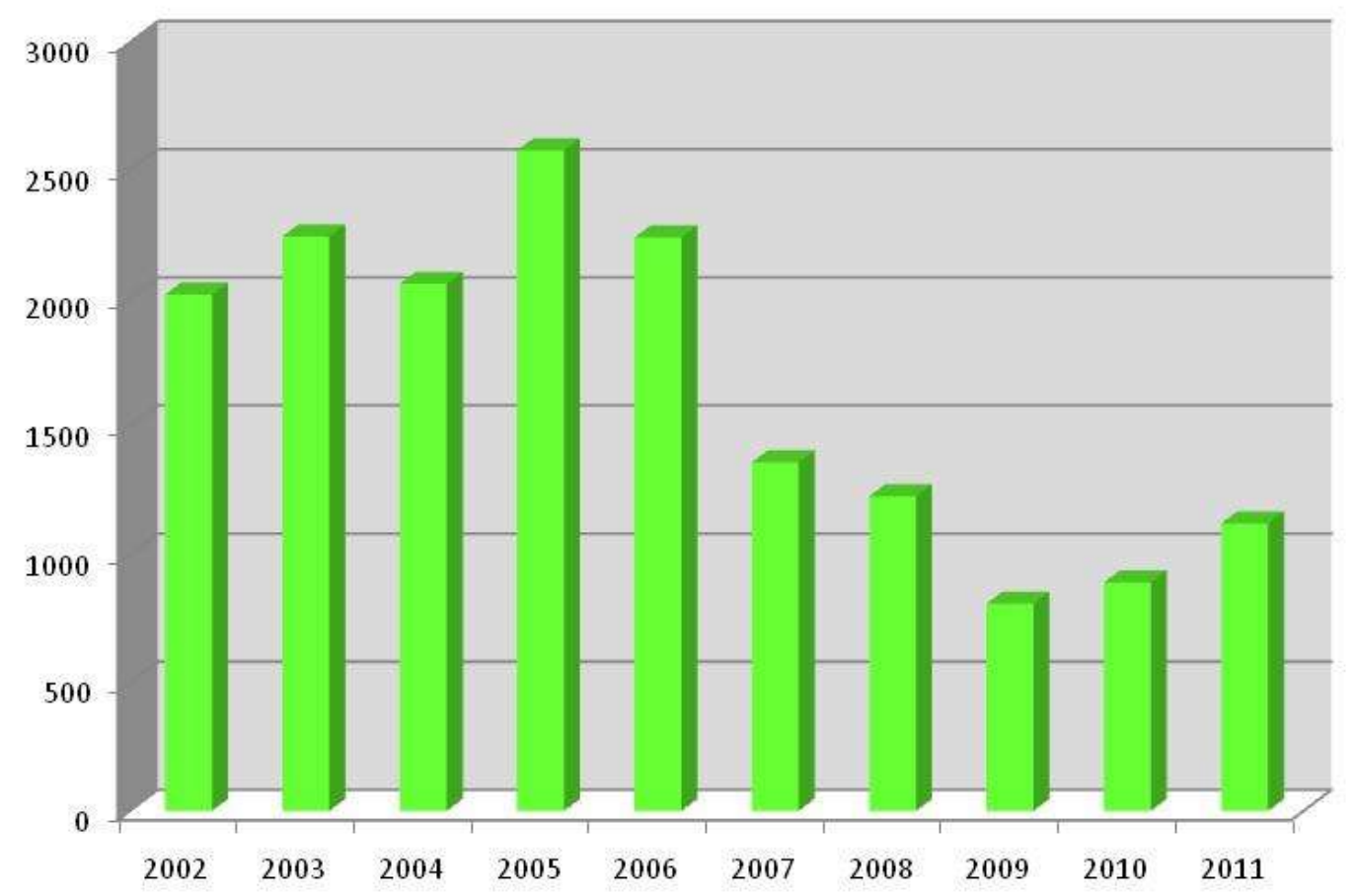

Рис. 1. Залежність зміни кількості відчеплень вагонів через нагрів букс, що були виявлені приладами автоматичного контролю та оглядачами вагонів

У результаті обробки статистичних даних про відчеплення вагонів на шляху прямування, наданих Головним управлінням вагонного господарства УЗ, одержана залежність, що характеризує зміну кількості відчеплень 3 цієї причини за період 1995-2011рр. (рис. 2). 


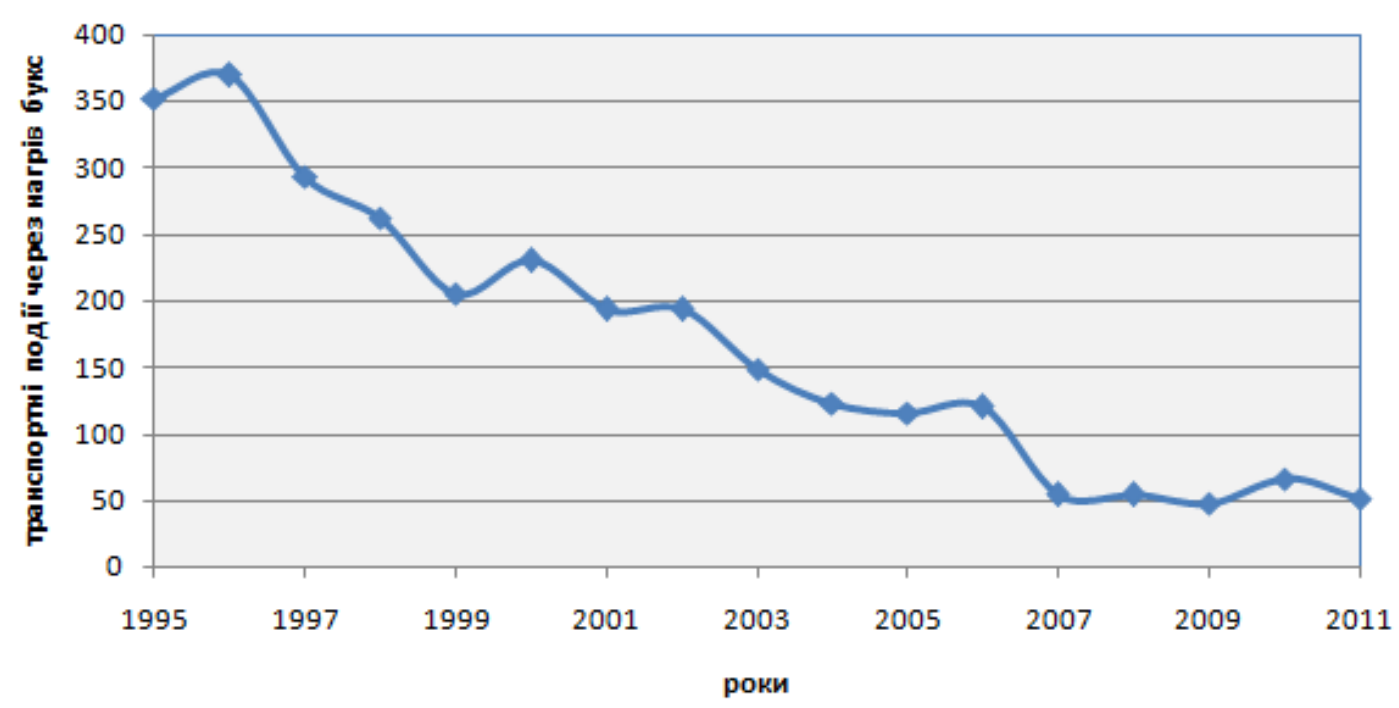

Рис. 2. Залежність зміни кількості відчеплень вагонів на шляху прямування через нагрів буксових підшипникових вузлів

Якщо починати відлік з 1995 року, то відповідна залежність буде мати такий вигляд:

$$
\Delta(t)=0,013 t^{4}-111,7 t^{3}-33562 t^{2}-4 \cdot 10^{8} t+2 \cdot 10^{11},
$$

де $t$ - роки, що відлічуються після 1995 року.

Ступінь узгодженості отриманої теоретичної залежності з експериментальними даними перевівся за допомогою коефіцієнта кореляції $R$, який визначався за формулою [0]

$$
R^{2}=1-\frac{\sum_{i=1}^{n}\left[y_{i}-f_{i}(t)\right]^{2}}{\sum_{i=1}^{n} y_{i}^{2}-\frac{1}{n} \cdot\left(\sum_{i=1}^{n} y_{i}\right)^{2}}
$$

де $y_{i}$ - емпіричні дані;

$f_{i}(t)$ - дані, що отримані розрахунковим способом;

$n$ - число пар даних.

На рис. 3 наведена залежність зміни параметра потоку відмов вантажних вагонів через відмови букс (у розрахунку на 1 млн ваг. км) за період 1995-2005 рр., оскільки саме цей показник дає змогу узагальнити зміни, які відбулися за цей час на залізничному транспорті: зменшення робочого парку вагонів, коливання вантажообігу, виключення вагонів 3 інвентарю і т. п.

Відповідна залежність для параметра потоку відмов вантажних вагонів через нагрів БВ має такий вигляд:

$$
\omega(t)=0,000008 t^{3}-0,005 t^{2}+99,28 t+65314,
$$

де $\omega$ - параметр потоку відмов, $\mathrm{t}$ - роки. 


\section{Рухомий склад залізниць}

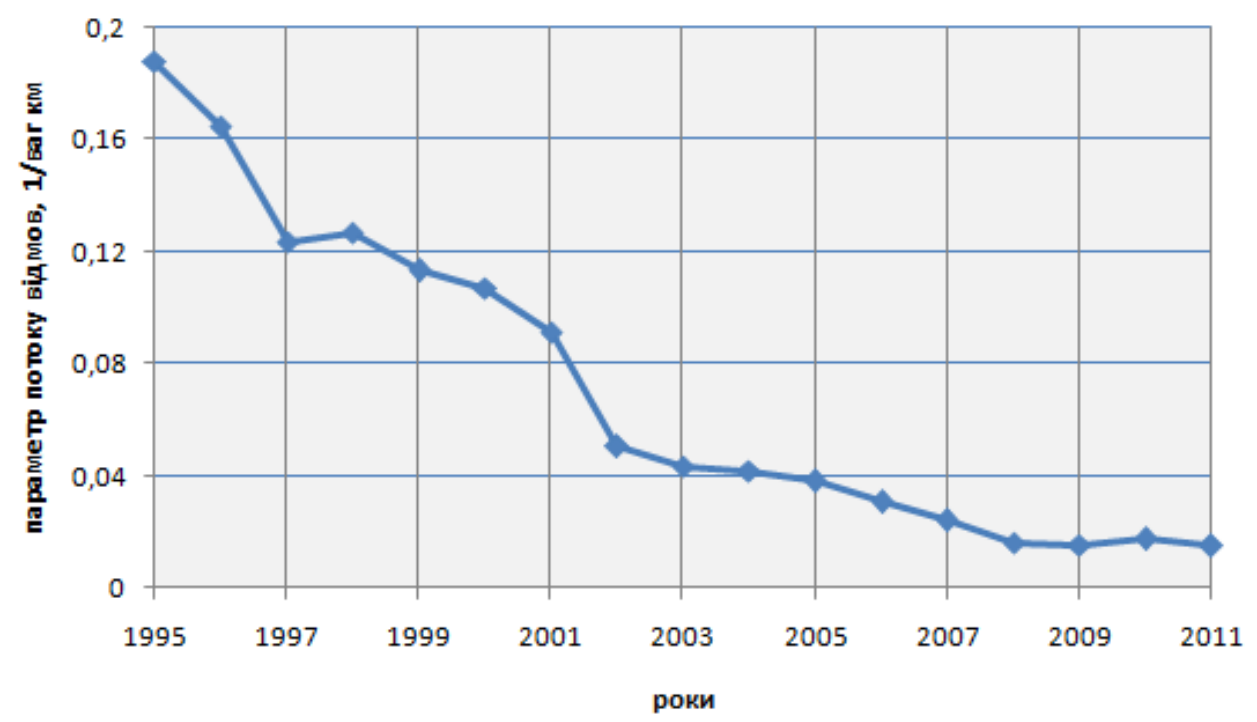

Рис. 3. Залежність зміни параметра потоку відмов вантажних вагонів через нагрів буксових вузлів

Наведені дані характеризують рівень надійності буксових вузлів стосовно загального парку вантажних вагонів. Оскільки за останні роки відбулася реструктуризація вагонного парку, внаслідок якої переважна більшість вагонів була розподілена між певними операторами, які стали не лише власниками вантажних вагонів, а й отримали відповідальність за підтримання вагонів у належному технічному стані.

На рис. 4 наведені результати, що характеризують параметр потоку відмов через пошкодження роликових букс для загального вагонного парку у порівнянні з парком критих універсальних вагонів у 2012 році.

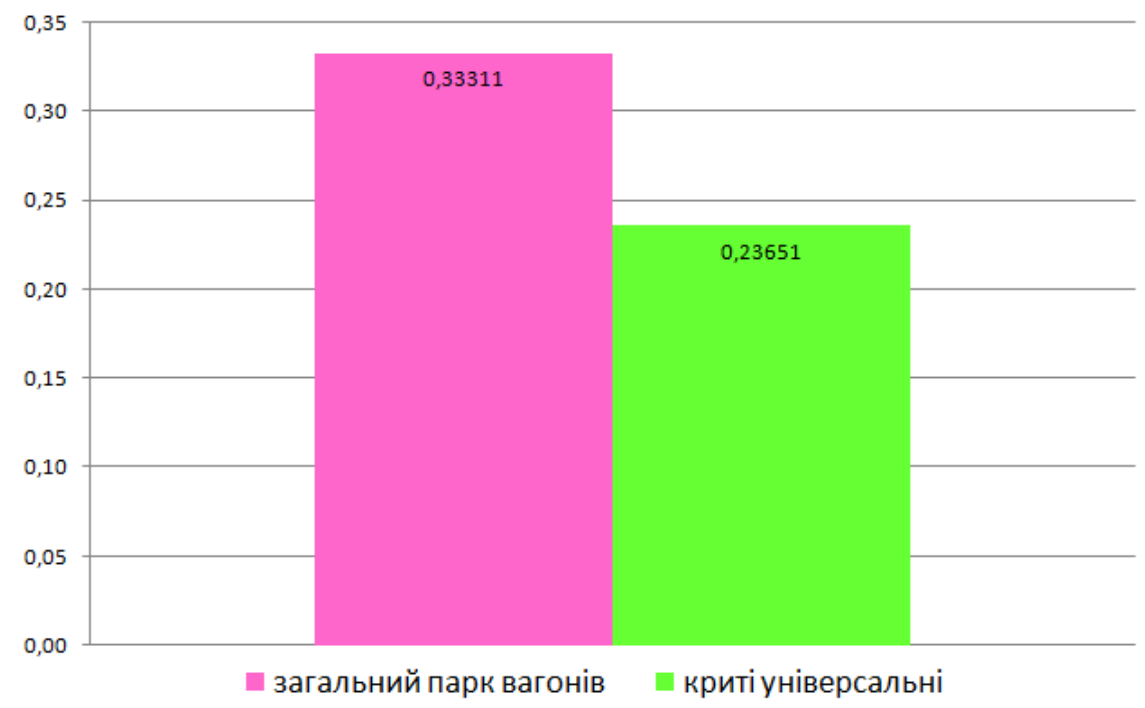

Рис. 4. Значення параметра потоку відмов вантажних вагонів через пошкодження буксових вузлів

Очевидно, що у критих універсальних вагонів параметр потоку відмов в 1,4 рази менше, тобто букси критих універсальних вантажних вагонів мають більший рівень надійністі. 
Висновки 3 дослідження і перспективи, подальший розвиток у даному напрямку. На основі обробки статистичного матеріалу про стан безпеки руху поїздів у вагонному господарстві запропонована модель визначення параметра потоку відмов вантажних вагонів через відмови буксових підшипникових вузлів (у розрахунку на 1 млн ваг. км). Результати розрахунків свідчать, що у критих універсальних вагонів параметр потоку відмов в 1,4 разу менше, інтенсивність використання вантажних вагонів різних типів дуже відрізняється. Це свідчить про можливість диференційованого підходу до визначення ресурсу буксових підшипників.

\section{Список використаних джерел}

1. Конструирование и расчёт вагонов [Текст]: учеб. для вузов ж.-д. трансп. / В.В. Лукин, Л.А. Шадур, В.Н. Котуранов [и др.]. - М.: УМК МПС России, 2000. - 731 с.

2. Девятков, В.Ф. Опыт эксплуатации буксовых узлов с роликовыми подшипниками вагонов грузового и пассажирского парка [Текст] / В.В. Девятков, В.В. Абашкин // Вопросы перевода подвижного состава на роликовые подшипники: труды ВНИИЖТ. - М.: Транспорт, 1961. - Вып. 221. - C. 16-24.

3. Цюренко, В.Н. Анализ эксплуатационного опыта работы роликовых подшипников в буксах вагонов / В.Н. Цюренко, Т.Н. Костеева [Текст] // Повышение надежности и долговечности роликовых подшипников в буксах вагонов: труды ВНИИЖТ. - М.: Транспорт, 1978. - Вып. 583. - С. 4-13.

4. Цюренко, В.Н. Надежность роликовых подшипников в буксах вагонов [Текст] / В.Н. Цюренко, В.А. Петров. - М.: Транспорт, 1982. - 96 с.

5. Мотовилов, К.В. Эксплуатационная надежность буксовых узлов вагонов [Текст] / К.В. Мотовилов, С.В. Перов, И.Э. Мартынов; Московский институт инженеров железнодорожного транспорта // Межвуз. сб. науч. тр. - М., 1988. - Вып. 804. - С. 92-99.

6. Мартынов, И.Э. Анализ опыта эксплуатации цилиндрических роликоподшипников букс грузовых вагонов [Текст] / И.Э. Мартынов // Вісник Східноукраїнського державного університету. Луганськ, 2000. - №5 (27). - С. 157-159.

7. Мартинов, I.Е. Технічний стан буксових роликопідшипників вантажних вагонів / I.Е. Мартинов [Текст] // Зб. наук. праць. - Харків: ХарДАЗТ, 2000. - Вип. 41. - С. 38-42.

8. Мартынов, И.Э. Анализ надежности буксовых узлов грузовых вагонов с подшипниками качения [Текст] / А.В. Донченко, И.Э. Мартынов, А.В. Труфанова // Безопасность движения поездов: труды IV науч.-практ. конф. - М., 2003. - C. IV.28-IV.29.

9. К вопросу внедрения вагонных букс с коническими роликоподшипниками [Текст] / А.Д. Лашко, В.В. Мархай, И.Э. Мартынов [и др.] // Залізничний транспорт України. - 2006. - № 2. C. $17-19$.

10. Вентцель, Е.С. Теория вероятностей [Текст] / Е.С. Вентцель. - М.: Гос. изд-во физ.-мат. лит., 1958. - 464 с.

\footnotetext{
Мартинов Ігор Ернстович, д-р техн. наук, професор кафедри вагонів Української державної академії залізничного транспорту. Тел.: (057) 730-10-36. E-mail: martinov.hiit@rambler.ru

Труфанова Альона Володимирівна, канд. техн. наук, доцент кафедри вагонів Української державної академії залізничного транспорту. Тел.: (057) 730-10-36. E-mail: alena.hiit@ rambler.ru

Ільчишин Василь Михайлович, здобувач кафедри вагонів Української державної академії залізничного транспорту. e-mail: ilvas@ukr.net
}

Martynov Igor Ernstovich, doct. of techn. sciences, professor of faculty of vagons Ukraine State Academy of Railway Transport. Tel.: (057) 730-10-36. E-mail: martinov.hiit@rambler.ru

Trufanova Alena Volodymyrivna, cand. of techn. sciences, lecturer of faculty of vagons Ukraine State Academy of Railway Transport. Tel.: (057) 730-10-35. E-mail: alena.hiit@ rambler.ru

Ilchishin Vasiiy Mihaylovich, engeneer of faculty of vagons Ukraine State Academy of Railway Transport. Tel.: (057) 730-10-35. E-mail: ilvas@ukr.net 